\title{
Polyphasic characterization of xanthomonads isolated from onion, garlic and Welsh onion (Allium spp.) and their relatedness to different Xanthomonas species
}

\author{
P. Roumagnac, ${ }^{1}$ L. Gagnevin, ${ }^{1}$ L. Gardan, ${ }^{2}$ L. Sutra, ${ }^{2}$ C. Manceau, ${ }^{2}$ \\ E. R. Dickstein, ${ }^{3}$ J. B. Jones, ${ }^{3}$ P. Rott ${ }^{4}$ and O. Pruvost ${ }^{1}$
}

Correspondence

Olivier Pruvost

olivier.pruvost@cirad.fr

\author{
${ }^{1}$ CIRAD, UMR Peuplement végétaux et Bioagresseurs en Milieu Tropical CIRAD/Université de \\ la Réunion, Ligne Paradis, 97410 Saint Pierre, Réunion Island, France \\ ${ }^{2}$ UMR de Pathologie Végétale, INRA, Station de Pathologie Végétale, 42 rue Georges Morel, \\ BP 57, 49071 Beaucouzé Cedex, France \\ ${ }^{3}$ Department of Plant Pathology, University of Florida, PO Box 110680, Gainesville, \\ FL 32611-0680, USA \\ ${ }^{4}$ UMR 385 ENSAM-INRA-CIRAD, Biologie et Génétique des Interactions Plante-Parasite, \\ Avenue Agropolis, 34398 Montpellier Cedex 5, France
}

\section{INTRODUCTION}

Bacterial blight of onion (BBO), caused by a Xanthomonas species, was initially observed in Barbados in 1971 (Paulraj \& O'Garro, 1993). The first characterization of the pathogen was performed in Hawaii, where the disease appeared in 1975 (Alvarez et al., 1978). A disease inducing similar symptoms was reported in mainland USA in the 1940s and ascribed to 'Xanthomonas striaformans' (Thomas \& Weinhold, 1953), but the biochemical characteristics of this species do not match those of the genus (Swings et al., 1993). BBO has subsequently been reported in many countries in the Americas, Asia and Africa (Isakeit et al., 2000; Kadota et al., 2000; Neto et al., 1987; Nunez et al.,

Published online ahead of print on 27 June 2003 as DOI 10.1099/ ijs.0.02714-0.

Abbreviations: AFLP, amplified fragment length polymorphism; BBO, bacterial blight of onion; CGM values, current genome mispairing values; FAFLP, fluorescent amplified fragment length polymorphism.

The GenBank accession number for the partial 16S rDNA sequence of Xanthomonas axonopodis pv. allii CFBP 6369 is AY135649.

Primer/adaptor sequences, a dendrogram based on FAME analysis, Biolog results and correspondence analysis and a fuller version of Fig. 1 are available as supplementary material in IJSEM Online.
2002; O'Garro \& Paulraj, 1997; Roumagnac et al., 1997; Sanders et al., 2003; Schwartz \& Otto, 2000; Serfontein, 2001; Trujillo \& Hernandez, 1999).

The taxonomic position of strains of Xanthomonas species pathogenic to onion has never been determined, neither in the reclassification of Xanthomonas performed by Vauterin et al. (1995), nor in a recent study comparing amplified fragment length polymorphism (AFLP) analysis and repetitive extragenic palindromic PCR (rep-PCR) to DNA-DNA relatedness in the genus Xanthomonas (Rademaker, 2000; Rademaker et al., 2000). Bacteria recently isolated from Welsh onion in Japan were considered to be a novel pathovar of Xanthomonas, and the name Xanthomonas campestris pv. allii pv. nov. was proposed (Kadota et al., 2000). This classification was, however, based only on biochemical and physiological characteristics and pathogenicity tests with a range of host plants, which is insufficient for species definition according to the recommendations of Wayne et al. (1987) and Stackebrandt et al. (2002). Kadota et al. (2000) have shown that the bacterium is pathogenic to onion and Welsh onion, but non-pathogenic to chive, Chinese chive and hyacinth. However, strains isolated in Barbados were pathogenic to onion, chive, leek, garlic, shallot (Bowen et al., 1998), French bean, soybean, 
winged bean, field pea, moth bean and lima bean (O'Garro \& Paulraj, 1997), whereas strains isolated in Hawaii were pathogenic to onion and Welsh onion, but not to bean (Alvarez et al., 1978).

Because of the partial characterization of the bacterium associated with $\mathrm{BBO}$ and the incomplete definition of its host range, the present study was initiated to characterize a large worldwide collection of BBO strains by a polyphasic approach based on 16S rRNA gene sequencing, DNA-DNA hybridization, analyses of carbon source utilization, fatty acid methyl esters and fluorescent amplified fragment length polymorphisms (FAFLPs) and pathogenicity tests. Based on the results obtained, the denomination Xanthomonas axonopodis pv. allii is proposed.

\section{METHODS}

Bacterial strains and media. Thirty-three strains of Xanthomonas species isolated from leaves of three Allium species, the type strains of 21 Xanthomonas species (Trébaol et al., 2000; Vauterin et al., 1995) and some additional Xanthomonas axonopodis pathovars were used in this study (Tables 1 and 2). Cultures were stored as lyophilized cells and/or in a freezer at $-80^{\circ} \mathrm{C}$; they were checked for purity and grown routinely on YPGA ( $7 \mathrm{~g}$ yeast extract, $7 \mathrm{~g}$ peptone,

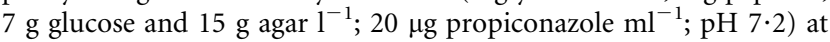
$28^{\circ} \mathrm{C}$, except Xanthomonas populi, which was grown at $19^{\circ} \mathrm{C}$. All strains included in this study were deposited in the Collection Française de Bactéries Phytopathogènes (CFBP, INRA Angers, France) and strain numbers used throughout are CFBP numbers, except where noted.

Pathogenicity tests. Onion (Allium cepa L. cv. Red Creole), chive (Allium schoenoprasum L. cv. Civette), garlic (Allium sativum L. cv. Vacoa), leek (Allium porrum L. cv. Gros long d'été), shallot (Allium cepa var. ascalonicum Backer cv. Ambition), bean (Phaseolus vulgaris L. cv. Michelet) and hyacinth (Hyacinthus orientalis L. cv. Carnegie) were inoculated with $21 \mathrm{BBO}$ strains (Table 1). Onion was screened as a potential host of $X$. axonopodis pv. phaseoli, because beans have been reported to be a host of the xanthomonad that causes BBO (O'Garro \& Paulraj, 1997). Onion was also inoculated with Xanthomonas hyacinthi, the only xanthomonad from the Liliaceae for which a taxonomic position has been clearly determined (Table 2). All bacterial suspensions used for pathogenicity tests were prepared in $0.01 \mathrm{M}$ Tris/ $\mathrm{HCl}$ buffer (Sigma; $\mathrm{pH} \mathrm{7.2)}$ ) and adjusted spectrophotometrically (Milton Roy Spectronic 601) to approximately $10^{8}$ c.f.u. $\mathrm{ml}^{-1}\left(\mathrm{OD}_{600}\right.$ of $\left.0 \cdot 05\right)$. These suspensions were further diluted in Tris buffer to reach the bacterial densities mentioned below. The Allium species (ten plants per species and strain) were spray-inoculated as described previously (Roumagnac et al., 2000) using bacterial suspensions containing approximately $10^{7}$ c.f.u. $\mathrm{ml}^{-1}$. Ten bean plants were inoculated per strain by finger-rubbing bacterial suspensions of approximately $10^{5}$ c.f.u. $\mathrm{ml}^{-1}$ on all trifoliate leaves of each plant. After inoculation, plants were covered with a translucent plastic bag for $48 \mathrm{~h}$. Four hyacinth plants were inoculated per strain by pricking the leaf with a needle and then infiltrating $0.5 \mathrm{ml}$ bacterial suspensions containing approximately $10^{5}$ c.f.u. $\mathrm{ml}^{-1}$. Negative controls consisting of four (hyacinth) or ten (bean and Allium spp.) individuals were inoculated similarly with sterile buffer in all experiments. All plants were placed in a growth chamber at a temperature of $30 \pm 1^{\circ} \mathrm{C}$, except for hyacinth $\left(12 \mathrm{~h}\right.$ per day at $24 \pm 1{ }^{\circ} \mathrm{C}$ and $12 \mathrm{~h}$ at $\left.18 \pm 1{ }^{\circ} \mathrm{C}\right)$, under a relative humidity of $95 \pm 5 \%$ and a photoperiod of $12 \mathrm{~h}$. Symptom appearance and progress were observed periodically after inoculation for 2 weeks. All experiments were repeated once.

\section{Phenotypic methods}

Biochemical and physiological characteristics. The BBO strains were cultivated on YPGA medium at $28^{\circ} \mathrm{C}$. Gram test, oxidationfermentation glucose metabolism, cytochrome $c$ oxidase activity, nitrate reduction, urease activity, indole production, hydrolysis of starch, aesculin, cellulose and Tween 80 , milk proteolysis, the presence of fluorescent pigments, production of $\mathrm{H}_{2} \mathrm{~S}$ from cysteine and tolerance to $\mathrm{NaCl}$ were assayed as described by Vernière et al. (1991). Pectinolytic activity and gelatin hydrolysis were respectively assayed according to Hildebrand (1971) and Lelliott et al. (1966).

Fatty acid methyl ester analysis. Strains were grown on medium containing nutrient broth (Difco) and $0.8 \%$ agar for $24 \mathrm{~h}$ at $28{ }^{\circ} \mathrm{C}$. Cultures were then transferred to a medium containing trypticase soy broth (BBL) and $0 \cdot 75 \%$ agar and were grown at $28^{\circ} \mathrm{C}$ for $24 \mathrm{~h}$. Strains 1976, 2532 and 4691 required 48 h incubation. Strain 4924 exhibited minimal growth on nutrient agar and was grown exclusively on TSBA. X. populi was not included in the analysis due to its very poor growth on all media tested. Extraction of fatty acids was performed according to the procedure described in MIDI Technical Note 101 (http://www.midi-inc.com/media/pdfs/TechNote_101.pdf). Bacterial strains were identified using the Sherlock TSBA40 version 4.00 method and a library running with the MIDI system version 4.13 DOS edition software. The GC system consisted of an HP 5890 GC, an HP 7673A autosampler and an HP 3396 series II integrator. Fatty acids were separated on an Ultra2 cross-linked 5\% PHME siloxane $25 \mathrm{M}$ column and detected with an FID. Hydrogen was used as the carrier gas. A dendrogram edited as described by Norman et al. (1997) was based on data from 32 BBO strains and 20 type strains of Xanthomonas species. Mean fatty acid profiles were generated using the library generation software.

Utilization of carbon sources. Six BBO strains $(6107,6359,6362$, 6367, 6369 and 6383) and the type strains of 19 Xanthomonas species were characterized phenotypically by the Biolog GN microplate system. Xanthomonas fragariae and $X$. populi were not analysed because of their poor reactivity in GN microplates. Experiments were performed as described by Vauterin et al. (1995). Two microplates were inoculated per strain and incubated at $28^{\circ} \mathrm{C}$ for $48 \mathrm{~h}$. Plates were then scored visually for carbon source utilization and $\mathrm{OD}_{590}$ were determined for the 96 wells using a microplate reader (Biotek EL 320). OD data were analysed by correspondence analysis with the software ADE-4 (Thioulouse et al., 1997). Groups of strains were defined by the Ward clustering method (Ward, 1963) using the same software. Biolog GN data were also used for identification purposes using the Microlog 1 software (Biolog) release 3.50.

\section{Molecular methods}

Sequencing of the 16S rRNA gene. Total DNAs of strains 6364, 6366, 6367 and 6369 were extracted by the CTAB method (Ausubel et al., 1991). Amplification of the 16S rRNA genes was performed by PCR as described by Nesme et al. (1995) using the specific primers FGPS6 (5'-GGAGAGTTAGATCTTGGCTCAG-3') and FGPS1509' (5'-AAGGAGGGGATCCAGCCGCA-3'). The amplified 16S rDNA fragments were purified with a QIAquick PCR purification kit (Qiagen) and cloned into the pGEM-T easy plasmid as recommended by the manufacturer (Promega). Sequence data were obtained by single-pass double-stranded analysis (Genome Express) using primers T7 and SP6, which flank the cloning region in the pGEM-T easy plasmid. Sequence data were compared with those of other xanthomonads (Hauben et al., 1997; Trébaol et al., 2000) by alignment using the CLUSTAL method of MEGALIGN (DNASTAR). 
Table 1. Levels of DNA reassociation between $X$. axonopodis pv. allii CFBP 6369 and strains pathogenic to Allium species used in this study

All strains listed in this table are currently known as $X$. axonopodis pv. allii.

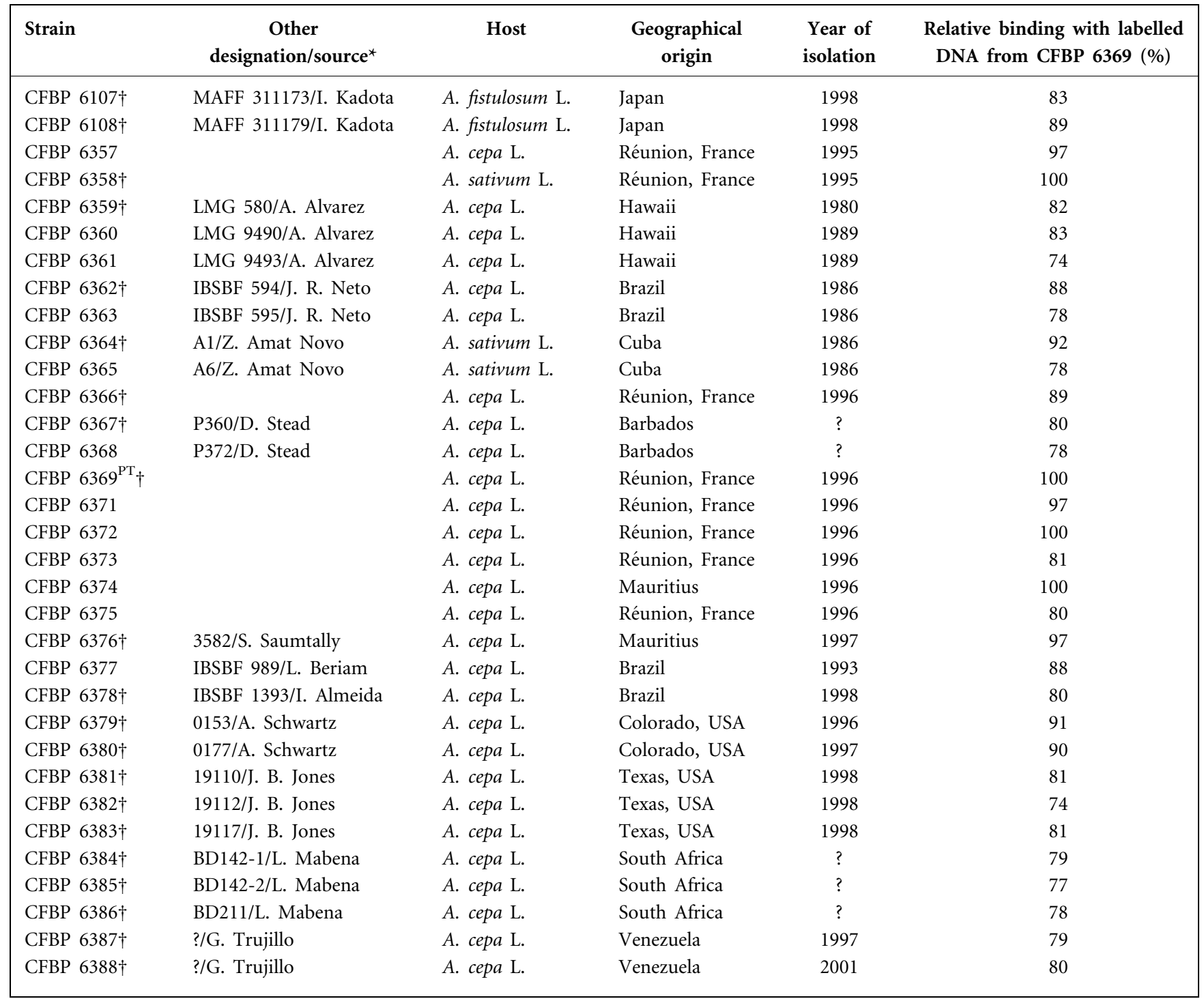

${ }^{*}$ Strains provided by: I. Kadota, National Institute of Agro-environmental Sciences, Tsukuba, Ibaraki 305-8604, Japan; A. Alvarez, Department of Plant Pathology, University of Hawaii, Honolulu, HI 96822, USA; J. R. Rodrigues Neto, L. Beriam and I. Almeida, Instituto Biológico, 1252 Vila Mariana, SP - Brazil; Z. Amat-Novo, Ministerio de la Agricultura, Centro Nacional de Sanidad Vegetal, Ciudad Habana, Cuba; D. Stead, Central Science Laboratory, Sand Hutton, York, UK; S. Saumtally, Mauritius Sugar Industry Research Institute, Le Reduit, Mauritius; A. Schwartz, Department of Bioagricultural Sciences \& Pest Management, Colorado State University, Fort Collins, CO, USA; J. B. Jones, Department of Plant Pathology, University of Florida, Gainesville, FL 32611, USA; L. Mabena, Plant Protection Research Institute, Agricultural Research Council, Pretoria, South Africa; and G. Trujillo, UCV, Fac. Agronomía, Instituto de Botánica Agrícola, Maracay, Venezuela.

$\dagger$ Strains used for pathogenicity tests on onion, garlic, chive, shallot, leek, bean and hyacinth. All strains listed in Table 1 were pathogenic to onion when inoculated according to the method described by Roumagnac et al. (2000).

DNA-DNA hybridization. DNA was extracted and purified according to Brenner et al. (1982). Native DNA of strain 6369 was labelled in vitro with tritium-labelled nucleotides by random priming using Megaprime DNA labelling system RPM 1604 (Amersham International). The S1 nuclease-trichloroacetic acid method used for DNA-DNA hybridization experiments was described by Crosa et al. (1973) and modified by Grimont et al. (1980). The reassociation temperature used was $70^{\circ} \mathrm{C}$. DNA-DNA hybridization experiments with tritium-labelled DNA of strain 6369 were performed at least twice.

Thermal stability of DNA reassociation. For strains that had DNA-DNA hybridization values of between 55 and $70 \%$ (Grimont, 1988 ) with strain 6369 , the temperature at which $50 \%$ reassociated 
Table 2. Levels of DNA reassociation between $X$. axonopodis pv. allii CFBP 6369, the type strains of 21 Xanthomonas species and the pathotype strains of three pathovars of $X$. axonopodis

\begin{tabular}{|c|c|c|}
\hline Strain $^{*}$ & Current nomenclature & $\begin{array}{l}\text { Relative binding (\%) with labelled } \\
\text { DNA from CFBP } 6369\left(\Delta T_{\mathrm{m}}\right)\end{array}$ \\
\hline \multicolumn{3}{|c|}{ Xanthomonas type strains } \\
\hline CFBP $1156^{\mathrm{T} \star}$ & X. hyacinthi & 19 \\
\hline CFBP $1817^{\mathrm{T}}$ & X. populi & 37 \\
\hline CFBP $1976^{\mathrm{T}}$ & X. bromi & 43 \\
\hline CFBP $2054^{\mathrm{T}}$ & X. translucens pv. translucens & 17 \\
\hline CFBP $2157^{\mathrm{T}}$ & $X$. fragariae & 27 \\
\hline CFBP $2523^{\mathrm{T}}$ & $X$. albilineans & 15 \\
\hline CFBP $2528^{\mathrm{T}}$ & X. arboricola pv. juglandis & 37 \\
\hline CFBP $2532^{\mathrm{T}}$ & $X$. oryzae pv. oryzae & 46 \\
\hline CFBP $2533^{\mathrm{T}}$ & $X$. hortorum pv. pelargonii & 37 \\
\hline CFBP $2542^{\mathrm{T}}$ & X. cucurbitae & 18 \\
\hline CFBP $2543^{\mathrm{T}}$ & $X$. vasicola pv. holcicola & 49 \\
\hline CFBP $4188^{\mathrm{T}}$ & X. cynarae & 41 \\
\hline CFBP $4641^{\mathrm{T}}$ & $X$. sacchari & 21 \\
\hline CFBP $4642^{\mathrm{T}}$ & X. cassavae & 40 \\
\hline CFBP $4643^{\mathrm{T}}$ & $X . p i s i$ & 40 \\
\hline CFBP $4644^{\mathrm{T}}$ & X. melonis & 34 \\
\hline CFBP $4645^{\mathrm{T}}$ & $X$. vesicatoria & 44 \\
\hline CFBP $4690^{\mathrm{T}}$ & $X$. codiaei & 44 \\
\hline CFBP $4691^{\mathrm{T}}$ & X. theicola & 11 \\
\hline CFBP $4924^{\mathrm{T}}$ & $X$. axonopodis pv. axonopodis & $55(0 \cdot 5)$ \\
\hline CFBP $5251^{\mathrm{T}}$ & $X$. campestris pv. campestris & 39 \\
\hline \multicolumn{3}{|c|}{ Strains of $X$. axonopodis pathovars } \\
\hline CFBP $1815^{\star}$ & X. axonopodis pv. phaseoli var. fuscans & ND \\
\hline CFBP 1816 & X. axonopodis pv. phaseoli var. fuscans & $\mathrm{ND}$ \\
\hline CFBP $2534^{\mathrm{PT} *}$ & $X$. axonopodis pv. phaseoli & $65(0 \cdot 2)$ \\
\hline CFBP $2524^{\mathrm{PT}}$ & $X$. axonopodis pv. begoniae & 67 \\
\hline CFBP $2525^{\mathrm{PT}}$ & $X$. axonopodis pv. citri & $\mathrm{ND}$ \\
\hline CFBP $2526^{\mathrm{PT}}$ & $X$. axonopodis pv. glycines & $\mathrm{ND}$ \\
\hline CFBP $2530^{\mathrm{PT}}$ & X. axonopodis pv. malvacearum & $\mathrm{ND}$ \\
\hline CFBP $2603^{\mathrm{PT}}$ & X. axonopodis pv. manihotis & 70 \\
\hline CFBP 2866 & X. axonopodis pv. aurantifolii & ND \\
\hline CFBP $3371^{\mathrm{PT}}$ & X. axonopodis pv. citrumelo & $\mathrm{ND}$ \\
\hline CFBP 3528 & X. axonopodis pv. aurantifolii & ND \\
\hline CFBP $3836^{\mathrm{PT}}$ & X. axonopodis pv. alfalfae & $\mathrm{ND}$ \\
\hline CFBP 5600 & X. axonopodis pv. vesicatoria & ND \\
\hline
\end{tabular}

ND, Not determined; ${ }^{\mathrm{T}}$, type strain; ${ }^{\mathrm{PT}}$, pathotype strain.

*Strains used to inoculate onion.

DNA became hydrolysable by nuclease $\mathrm{S} 1\left(T_{\mathrm{m}}\right)$ was determined using the method of Crosa et al. (1973). The $\Delta T_{\mathrm{m}}$ value corresponds to the $T_{\mathrm{m}}$ value of the homoduplex (strain 6369) minus the $T_{\mathrm{m}}$ value of the heteroduplex.

DNA base composition. The $\mathrm{G}+\mathrm{C}$ contents (mol\%) of strains $6107,6369,6381$ and 6385 were determined by the thermal denaturation method (Marmur \& Doty, 1962) and calculated using the equation of Owen \& Lapage (1976).

Fluorescent AFLP (FAFLP) analysis. Six BBO strains (6107, 6359, 6362, 6367, 6369 and 6383), all type strains of Xanthomonas species, except that of X. populi, and 12 strains of $X$. axonopodis (Table 2) were submitted to FAFLP analysis. Genomic DNA was extracted and purified as described by Brenner et al. (1982) and/or using the DNeasy tissue kit (Qiagen). To test the reproducibility of the FAFLP technique, strain 6369 was used as a control in each independent AFLP experiment (15 runs). To test the consistency of the two extraction methods, DNA of strain 6369 extracted by both methods was submitted to the FAFLP protocol in three independent experiments. Two reaction mixtures were prepared for digestion and ligation. For the first mixture, $5 \mu$ l genomic DNA $\left(2 \mathrm{ng}^{-1} \mathrm{l}^{-1}\right)$ was mixed in a total volume of $15 \mu \mathrm{l}$ with $3.6 \mathrm{U}$ of each restriction enzyme EcoRI and MspI (Eurogentec), $2 \mu \mathrm{l} 0.5 \mathrm{M} \mathrm{NaCl}, 0 \cdot 2 \mu \mathrm{l}$ $100 \times$ BSA solution (Biolabs), $1.5 \mu 110 \times$ T4 ligase buffer (Biolabs), $1 \mu \mathrm{l} 2 \mu \mathrm{M}$ EcoRI adaptor (Cybergène) and $1 \mu \mathrm{l} 20 \mu \mathrm{M}$ MspI adaptor (Cybergène). The second mixture was prepared in a total volume of $5 \mu \mathrm{l}$, with $0 \cdot 5 \mu \mathrm{l} 10 \times \mathrm{T} 4$ ligase buffer and $100 \mathrm{U}$ T4 DNA ligase 
(Biolabs). The two reaction mixtures were combined and incubated for $3 \mathrm{~h}$ at $37^{\circ} \mathrm{C}$. After incubation, the reaction mixture was diluted tenfold with distilled water.

Two successive amplification reactions were then performed. Firstly, amplification was performed in $20 \mu \mathrm{l}$ containing $4 \mu \mathrm{l}$ diluted DNA from the restriction-ligation step, $2 \mu \mathrm{l} 10 \times$ Goldstar buffer (Eurogentec), $5 \mathrm{mM} \mathrm{MgCl}, 2 \mathrm{mM}$ dNTPs, $0 \cdot 25 \mu \mathrm{M}$ each of EcoRI and MspI primer and $0.5 \mathrm{U}$ Taq DNA polymerase (Goldstar red; Eurogentec). This pre-selective amplification consisted of incubation of the reaction mixture for $2 \mathrm{~min}$ at $72{ }^{\circ} \mathrm{C}$ followed by 20 cycles with the following cycle profile: a $20 \mathrm{~s}$ DNA denaturation step at $94^{\circ} \mathrm{C}$, $30 \mathrm{~s}$ annealing step at $56^{\circ} \mathrm{C}$ and $2 \mathrm{~min}$ extension step at $72^{\circ} \mathrm{C}$. PCR products were then diluted tenfold with distilled water. Secondly, a selective amplification using a $5^{\prime}$-JOE-labelled selective EcoRI primer $(E c o R I+G$ primer $)$ and the unlabelled selective MspI primer (MspI + TG primer) was performed in a $20 \mu \mathrm{l}$ reaction mixture containing $1.5 \mu$ ldiluted pre-amplified DNA from the previous PCR, $2 \mu \mathrm{l} 10 \times$ Goldstar buffer (Eurogentec), $2.5 \mathrm{mM} \mathrm{MgCl} 2,2 \mathrm{mM}$ dNTPs, $50 \mathrm{nM}$ labelled selective EcoRI primer, $250 \mathrm{nM}$ selective $M s p \mathrm{I}$ primer and $0.5 \mathrm{U}$ Taq DNA polymerase (Goldstar red; Eurogentec). Sequences of the adaptors, primers and selective primers used in FAFLP are available in Supplementary Table A in IJSEM Online. The selective amplification consisted of a 2 min denaturation step at $94{ }^{\circ} \mathrm{C}$, followed by 33 cycles of a DNA denaturation step at $94{ }^{\circ} \mathrm{C}$ for $20 \mathrm{~s}$, a $30 \mathrm{~s}$ annealing step (see below) and a 2 min extension step at $72^{\circ} \mathrm{C}$. The annealing temperature was $66^{\circ} \mathrm{C}$ for the first cycle and was then decreased by $1{ }^{\circ} \mathrm{C}$ per cycle for the next 9 cycles and was $56^{\circ} \mathrm{C}$ for the last 23 cycles. A final extension step was performed at $60^{\circ} \mathrm{C}$ for $30 \mathrm{~min}$. Amplification reactions were performed in a PE-9700 thermocycler (Applied Biosystems). One microlitre from the selective amplification was added to $18 \cdot 2 \mu \mathrm{l}$ formamide and $0 \cdot 3 \mu \mathrm{l}$ GENESCAN TAMRA-500 ladder as an internal standard (Perkin Elmer) and denatured at $95^{\circ} \mathrm{C}$ for $3 \mathrm{~min}$. Samples were then submitted to capillary electrophoresis for $35 \mathrm{~min}(15 \mathrm{kV})$ in an ABI-310 Genetic Analyzer (Applied Biosystems) with performance optimized polymers POP-4. The FAFLP fingerprints were superimposed and compared visually using GENESCAN software (Applied Biosystems). The threshold for assigning a peak was set to 100 relative fluorescence. The presence and absence of fragments were scored in a binary matrix. A similarity matrix using the Jaccard coefficient was calculated (NTSYS 2.0) and an unweighted neighbourjoining tree (Gascuel, 1997) was built using DARWIN 4.0 software (CIRAD). The robustness of the tree was assessed by bootstrap analysis using the same software (1000 repeated samplings). Current genome mispairing (CGM) values were calculated as described by Mougel et al. (2002). CGMs are obtained from the mathematical transformation of Jaccard similarity coefficients into genetic distances, which takes into account the number of nucleotide sites that constrain the AFLP technique (Mougel et al., 2002).

\section{RESULTS}

\section{Pathogenicity tests}

All Xanthomonas strains isolated from Allium spp. induced typical symptoms, i.e. water-soaked leaf spots that turned into dry chlorotic lesions, on four out of the five Allium spp. assayed (onion, garlic, shallot and leek). On chive, watersoaked lesions developed further into a generalized chlorosis between the lesion and the top of the leaf. No symptoms appeared on hyacinths inoculated with the BBO strains. The type strain of $X$. hyacinthi and X. axonopodis pv. phaseoli induced typical lesions on their respective hosts, but were not pathogenic to onion. Small, water-soaked lesions that became necrotic in about 7 days were sometimes observed on bean after inoculation with BBO strains. In contrast, $X$. axonopodis pv. phaseoli incited typical symptoms of common blight, with development of large, translucent lesions that resulted in a progressive disease with little or no early necrosis. Consequently, BBO strains were considered to be non-pathogenic to bean.

\section{Phenotypic traits}

Biochemical and physiological characteristics. The BBO strains formed single colonies on YPGA medium after 3 days incubation at $28^{\circ} \mathrm{C}$. Colonies were yellow, convex, round and mucoid. Cells were Gram-negative rods. Strains were obligate aerobes and glucose was utilized oxidatively. Starch, gelatin, aesculin, cellulose and Tween 80 were hydrolysed. Proteolysis of milk occurred. Cytochrome $c$ oxidase and urease were not detected. Indole was not produced and nitrates were not reduced. Fluorescent pigments were not produced. Strains produced $\mathrm{H}_{2} \mathrm{~S}$ from cysteine and showed pectinolytic activity at $\mathrm{pH}$ values of $5 \cdot 0,7 \cdot 0$ and $8 \cdot 5$. Cells grew on YPGA medium containing up to $3 \% \mathrm{NaCl}$.

Analysis of fatty acid methyl ester composition. A dendrogram based on fatty acid methyl ester profiles of 32 BBO strains and 20 type strains of Xanthomonas species is available as Supplementary Fig. A in IJSEM Online. Thirty of the $32 \mathrm{BBO}$ strains formed a cluster with a Euclidian distance of less than $6 \cdot 3$; strain groupings were unrelated to geographical origin or host. Type strains of Xanthomonas codiaei, Xanthomonas cynarae and Xanthomonas translucens also fell into this same cluster. Removing these strains from the dendrogram did not change the Euclidian distance between the onion strains (data not shown). There were two outliers (6107 and 6108 from Japan), with a Euclidian distance of approximately $9 \cdot 8$.

The onion strains and the two outliers each had over 20 fatty acids (data not shown). In both groups, three fatty acids, $15: 0$ iso, $15: 0$ anteiso and summed feature $3(16: 1 \omega 7 c / 15$ iso $2-\mathrm{OH}$ ) accounted for $>50 \%$ of each profile. Beyond that, the relative occurrence of other fatty acids differed in the two profiles (Table 3 ).

Utilization of carbon sources. Percentages of metabolic activities of $33 \mathrm{BBO}$ strains with 95 carbon sources of the Biolog GN microplate are shown in Supplementary Table B in IJSEM Online. The 33 BBO strains were able to metabolize 32 of 95 carbon sources and all strains were identified as Xanthomonas spp. Phenotypic relationships between BBO strains and other xanthomonads based on correspondence analysis of metabolic fingerprints are shown in Supplementary Fig. B in IJSEM Online.

According to the correspondence analysis, the first three principal components respectively accounted for 38, 13 and $11 \%$ of total variance. Ward clustering analysis revealed 
Table 3. Relative occurrence of the most common fatty acids in 30 BBO strains and two outlier strains (6107 and 6108)

Values are mean percentages \pm SD.

\begin{tabular}{|lrr|}
\hline Fatty acid & BBO strains & Outliers \\
\hline $15: 0$ iso & $26 \cdot 45 \pm 2 \cdot 20$ & $32 \cdot 46 \pm 0 \cdot 22$ \\
Summed feature $3^{*}$ & $18 \cdot 24 \pm 1 \cdot 14$ & $18 \cdot 64 \pm 0 \cdot 09$ \\
$15: 0$ anteiso & $9 \cdot 43 \pm 1 \cdot 53$ & $9 \cdot 18 \pm 0 \cdot 48$ \\
$17: 0$ iso & $8 \cdot 45 \pm 1 \cdot 55$ & $3 \cdot 05 \pm 0 \cdot 31$ \\
isol7:1 $\omega 9 c$ & $5 \cdot 83 \pm 1 \cdot 23$ & $2 \cdot 82 \pm 0 \cdot 17$ \\
$16: 0$ & $5 \cdot 70 \pm 0 \cdot 94$ & $4 \cdot 65 \pm 0 \cdot 38$ \\
$13: 0$ iso 3-OH & $3 \cdot 93 \pm 0 \cdot 33$ & $4 \cdot 42 \pm 0 \cdot 20$ \\
$11: 0$ iso & $3 \cdot 75 \pm 0 \cdot 37$ & $4 \cdot 43 \pm 0 \cdot 13$ \\
$12: 0$ 3-OH & $3 \cdot 03 \pm 0 \cdot 34$ & $2 \cdot 92 \pm 0 \cdot 00$ \\
$16: 0$ iso & $2 \cdot 13 \pm 0 \cdot 84$ & $1 \cdot 51 \pm 0 \cdot 19$ \\
$16: 1 \omega 9 c$ & $1 \cdot 84 \pm 0 \cdot 36$ & $2 \cdot 11 \pm 0 \cdot 13$ \\
$11: 0$ iso 3-OH & $1 \cdot 76 \pm 0 \cdot 18$ & $1 \cdot 94 \pm 0 \cdot 15$ \\
Unknown $11 \cdot 799$ & $1 \cdot 49 \pm 0 \cdot 15$ & $1 \cdot 48 \pm 0 \cdot 05$ \\
$14: 0$ & $1 \cdot 32 \pm 0 \cdot 37$ & $3 \cdot 33 \pm 0 \cdot 39$ \\
$15: 0$ & $1 \cdot 16 \pm 0 \cdot 39$ & $1 \cdot 51 \pm 0 \cdot 13$ \\
\hline
\end{tabular}

${ }^{\star}$ Summed feature 3 contains $16: 1 \omega 7 c / 15$ iso $2-\mathrm{OH}$.

the presence of four groups of strains. Superimposition of groups on the graph showing the first two components allowed discriminating carbon sources to be easily identified. The six BBO strains studied clustered in group 1, together with Xanthomonas sacchari, Xanthomonas arboricola pv. juglandis and Xanthomonas pisi; X. campestris pv. campestris, X. codiaei, Xanthomonas melonis and Xanthomonas cassavae formed group 2. Xanthomonas albilineans was the only species of group 3; and group 4 included the other 11 type strains of Xanthomonas species. The most characteristic substrates were D-saccharic acid for group 2 and D-mannitol and D-gluconic acid for group 3. Strains that belonged to groups 1 and 4 did not utilize these three carbon sources. Group 1 strains utilized cellobiose, D-galactose, gentiobiose, lactulose and $\alpha$-ketoglutaric acid, whereas strains of group 4 did not. Within group 1, BBO strains could be differentiated from $X$. sacchari by the utilization of quinic acid, from $X$. arboricola pv. juglandis by the utilization of dextrin, glycogen and maltose and from X. pisi by the utilization of cis-aconitic acid.

\section{Molecular characterization}

Sequencing of the 16S rRNA gene. A fragment of $1499 \mathrm{bp}$ corresponding to positions $28-1529$ of the $16 \mathrm{~S}$ rDNA of Escherichia coli was amplified by PCR and sequenced for each of the four BBO strains. The $16 \mathrm{~S}$ rDNA sequences of the four $\mathrm{BBO}$ strains analysed were $100 \%$ identical, but this sequence differed by at least one base from the equivalent sequence of each of the 21 species of Xanthomonas studied. The 16S rDNA sequence of the BBO strains showed similarities to sequences of the other xanthomonads ranging from $96 \cdot 7 \%$ (X. hyacinthi and $X$. translucens) to more than $99 \%$ (Xanthomonas vasicola, X. arboricola, Xanthomonas hortorum, X. campestris, X. cynarae, Xanthomonas oryzae, X. pisi, X. cassavae, Xanthomonas vesicatoria, Xanthomonas cucurbitae, Xanthomonas bromi, X. codiaei, X. populi, X. fragariae and X. axonopodis).

DNA-DNA hybridization and $\Delta T_{\mathrm{m}}$ values. DNA-DNA hybridization values between strain 6369 and the other BBO strains were higher than $70 \%$ (Table 1). In contrast, DNA-DNA hybridization values between strain 6369 and the 21 type strains of Xanthomonas species and the type strains of three pathovars of $X$. axonopodis were lower than $70 \%$ (Table 2). The percentage reassociation of strain 6369 was $55 \%$ with X. axonopodis pv. axonopodis strain 4924 and $11-49 \%$ with the other 20 type strains of Xanthomonas. The pathotype strains of three pathovars of $X$. axonopodis ( $\mathrm{pv}$. manihotis, pv. begoniae and pv. phaseoli) were $65-70 \%$ related to strain 6369 . The $\Delta T_{\mathrm{m}}$ values were $0.2^{\circ} \mathrm{C}$ between strains 6369 and 2534 (pv. phaseoli) and $0.5{ }^{\circ} \mathrm{C}$ between strains 6369 and 4924 (pv. axonopodis).

DNA base composition. The DNA $\mathrm{G}+\mathrm{C}$ contents of strains $6107,6369,6381$ and 6385 were respectively $62 \cdot 7$, $62 \cdot 7,62 \cdot 3$ and $62 \cdot 3 \mathrm{~mol} \%$.

FAFLP analysis. Data derived from 15 different runs performed with strain 6369 allowed non-reproducible band positions to be identified; these were not considered for band scoring of all runs and strains. The composition of FAFLP patterns was not influenced by the DNA extraction method and the different runs differed only by one or two bands among 43 bands. The high reproducibility of FAFLP was further supported by maximal bootstrap values when data from DNA samples extracted by both techniques were included in the data matrix (results not shown).

A total of 147 fragments was generated and all these fragments were polymorphic. FAFLP analysis generated 62 fragments for the $\mathrm{BBO}$ strains; $63 \%$ of these fragments were polymorphic. All BBO strains clustered with pathotype strains of $X$. axonopodis pv. vesicatoria, pv. citrumelo and pv. alfalfae (Fig. 1). A fuller phylogenetic tree is available as Supplementary Fig. C in IJSEM Online.

The bootstrap value of the node grouping these strains was $63 \%$. Some pathotype strains of $X$. axonopodis pathovars were closely related (e.g. pv. citri and pv. malvacearum, pv. alfalfae and pv. citrumelo). Among all Xanthomonas species, $X$. axonopodis was the most closely related to the BBO strains. Furthermore, the type strains of Xanthomonas species were weakly related to each other.

CGM values between strains belonging to different Xanthomonas species ranged from $6 \cdot 0$ (between X. oryzae $2532^{\mathrm{T}}$ and X. axonopodis pv. alfalfae 3836) to $13 \cdot 8 \%$ (between $X$. fragariae $2157^{\mathrm{T}}$ and $X$. axonopodis pv. begoniae 2524). The mean CGM values were $3 \cdot 6 \pm 0 \cdot 6 \%$ between $\mathrm{BBO}$ strains and 


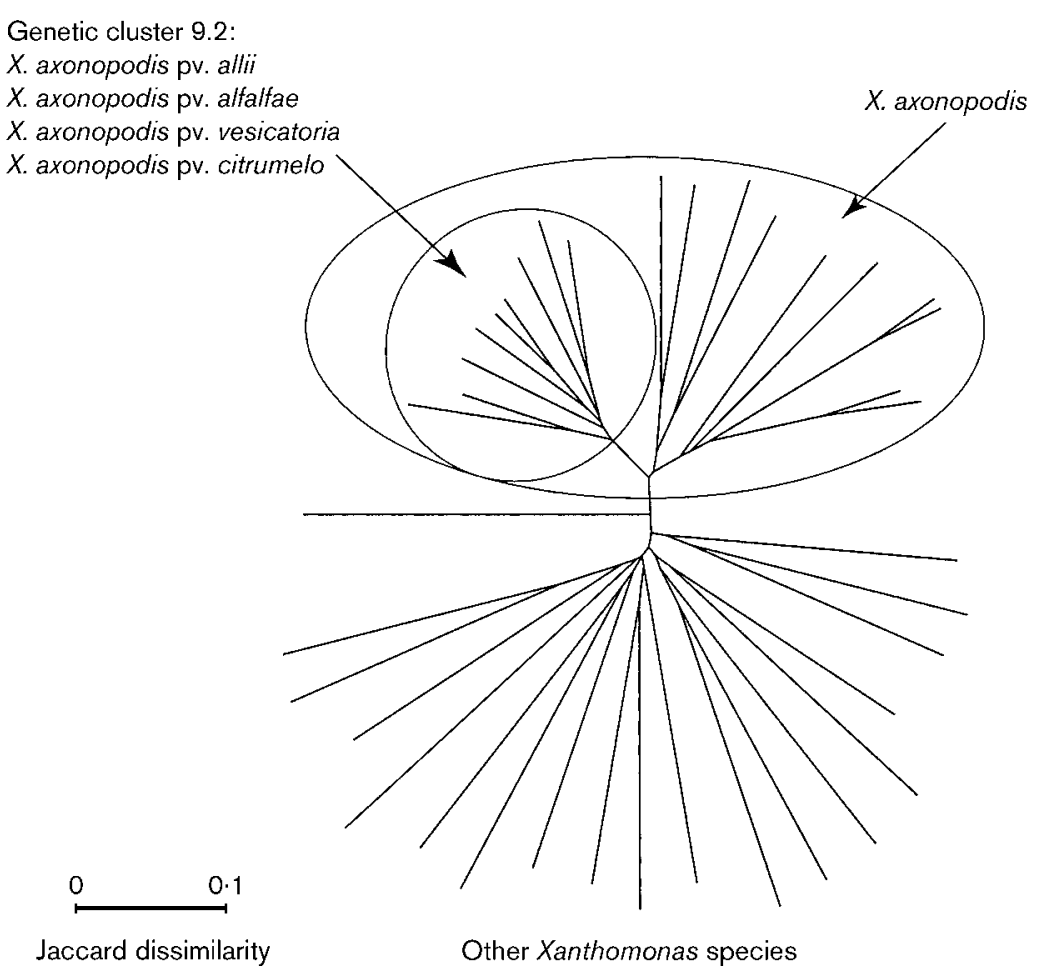

Fig. 1. Simplified unweighted neighbourjoining tree showing the relationships between type strains of Xanthomonas species and BBO strains based on 147 FAFLP fragments.
$5 \cdot 5 \pm 1 \cdot 5 \%$ between strains of $X$. axonopodis. Comparison of CGMs and DNA-DNA reassociation values showed that genome mispairing was negatively and linearly correlated to DNA-DNA hybridization values $\left(r^{2}=0 \cdot 80\right)$.

\section{DISCUSSION}

$\mathrm{BBO}$ is an emerging disease that may have an increasing economic impact in future. The causal agent, recently isolated from Welsh onion in Japan, has been described as Xanthomonas campestris pv. allii pv. nov. (Kadota et al., 2000). The species allocation made by these authors, based solely on a biochemical and physiological characterization, does not meet the recommendations of Wayne et al. (1987) and Stackebrandt et al. (2002). Our study was performed to assess the accurate taxonomic position of the bacterium. To achieve this, a worldwide collection of strains of xanthomonads pathogenic to Allium species was examined by appropriate methods recommended for the taxonomic description of bacterial species (Stackebrandt et al., 2002). Moreover, international standards for naming pathovars of phytopathogenic bacteria were also used (Dye et al., 1980).

In accordance with the results of phenotypic characterization, 16S rDNA sequence similarities indicated that the $\mathrm{BBO}$ strains belong to the genus Xanthomonas and should be added to the $X$. campestris core described previously by Hauben et al. (1997). However, 16S rDNA sequence analysis is known to be limited in terms of taxonomic resolution at the species level for members of the genus Xanthomonas (Moore et al., 1997).
Taxonomic relationships at the species level were assessed by DNA-DNA hybridization, thermal stability of DNA reassociation and FAFLP analysis. All BBO strains belonged to a single genomospecies, as indicated by DNA reassociation values with BBO strain 6369, which were 74-100\%. Several reports indicated that xanthomonads associated with a single disease phenotype can belong to more than one Xanthomonas genomospecies (Jones et al., 2000; Vauterin et al., 1995).

The type strains of Xanthomonas species were only 11-55 \% related to strain 6369 . The most closely related type strain was $X$. axonopodis (with $55 \%$ DNA reassociation). This is below the $70 \%$ threshold allowed for species definition (Wayne et al., 1987). However, three other pathovars belonging to $X$. axonopodis included in our study showed $65-70 \%$ DNA relatedness to strain 6369. The close relationship between the $\mathrm{BBO}$ strains and $X$. axonopodis was confirmed by the low $\Delta T_{\mathrm{m}}$ values $\left(0 \cdot 2\right.$ and $\left.0.5^{\circ} \mathrm{C}\right)$ obtained with strains 2534 (X. axonopodis pv. phaseoli) and 4924 (X. axonopodis pv. axonopodis), respectively. These values, which are much lower than the $5^{\circ} \mathrm{C} \Delta T_{\mathrm{m}}$ threshold (Wayne et al., 1987), indicate that the BBO causal agent should be included in the species $X$. axonopodis [i.e. group 9 defined by Vauterin et al. (1995)]. Other xanthomonads (e.g. pv. coracanae, pv. phaseoli, pv. sesbaniae, pv. vitians) with less than $70 \%$ DNA relatedness to $X$. axonopodis have previously been allocated to this species (Trébaol et al., 2000; Vauterin et al., 1995). Thus, our data further confirm that $X$. axonopodis has a wider internal genetic variability than is commonly found in Xanthomonas species. Results from FAFLP analysis further confirmed that BBO strains were 
more similar to $X$. axonopodis than to any other Xanthomonas species. The unweighted neighbour-joining tree inferred from FAFLP patterns showed that BBO strains clustered with three pathovars of $X$. axonopodis, $\mathrm{pv}$. vesicatoria, pv. citrumelo and pv. alfalfae. This is in full agreement with the results of Janssen et al. (1996), who used a different set of restriction enzymes and selective primers for AFLP and showed that X. axonopodis formed two clusters. One of them, cluster I, consisted of three subdivisions, $\alpha, \beta$ and $\gamma$; the $\gamma$ subdivision contained the two pathovars alfalfae and citrumelo (pv. vesicatoria was not included in their study) with a linkage level of $71 \cdot 0 \pm 3 \cdot 7 \%$. In our case, the linkage level, calculated with the same index as Janssen et al. (1996), between strains of the 'alfalfae-citrumelo-vesicatoria-BBO' group was $67 \cdot 6 \%$ (data not shown). Similarly, Rademaker et al. (2000) analysed 80 AFLP and 178 rep-PCR (rep-, BOX- and ERIC-PCR) fingerprints of Xanthomonas strains. X. axonopodis consisted of six genetic clusters. Pathovars alfalfae, citrumelo and vesicatoria all belonged to the same group, designated 9.2 (Rademaker, 2000). In addition to the results of Rademaker et al. (2000), our study indicates that AFLP data are well correlated with DNA-DNA hybridization data at the species level and, therefore, the allocation of $\mathrm{BBO}$ strains to the species $X$. axonopodis was confirmed.

The CGM value provides an accurate measure of the genetic distance between genomes (Mougel et al., 2002). From data obtained on Agrobacterium (Mougel et al., 2002), a CGM of $13.6 \%$ corresponded to the usual $70 \%$ hybridization threshold above which strains are considered to belong to a single species (Wayne et al., 1987). In our study, the maximal CGM value obtained between Xanthomonas type strains and the $\mathrm{BBO}$ strain used as a probe for DNA-DNA hybridization was $9 \cdot 1 \%$, indicating that AFLP profiles of distinct species of Xanthomonas may be closer than those of distinct species of Agrobacterium. Furthermore, a highly significant linear relationship between CGM and DNA-DNA hybridization values was found over the whole range of values. Our data further confirm the conclusions of Mougel et al. (2002), who stated that the correspondence between CGM and the threshold of $70 \%$ DNA relatedness must be established with care for different bacterial genera.

Correspondence analysis was used to compare metabolic fingerprints obtained from the type strains of Xanthomonas species and six BBO strains. This statistical method has already been used for phenotypic characterization of bacterial populations, and its major advantages for eliminating bias related to the Biolog technique have already been discussed (Frey et al., 1997; Garland, 1996). BBO strains grouped with $X$. sacchari, $X$. arboricola pv. juglandis and $X$. pisi. Correspondence analysis resulted in determination of the most useful carbon sources for identification purposes. However, metabolic fingerprints of type strains of Xanthomonas species obtained in this study differed from those reported by Trébaol et al. (2000) and Vauterin et al. (1995), which also differed from each other. Scortichini \& Rossi (1995) reported that subculturing influenced carbohydrate utilization profiles of X. campestris pv. campestris. Recently, Riley et al. (2001) reported that carbon utilization profiles were variable among Ralstonia populations evolved in defined environments for 1000 generations. Most of the type strains of Xanthomonas species were isolated more than 30 years ago, and changes in phenotypic traits could have occurred. Such changes could be related to the mode and duration of conservation, the number of successive strain subcultures and occurrence of stresses during exchanges of cultures, etc. The lack of stability of phenotypic traits probably represents a bias when xanthomonad strains from culture collections are compared, and emphasizes the difficulty of comparing metabolic fingerprints obtained in a laboratory with previously published information. As a consequence, the lack of reproducibility questions the power of the Biolog technique for locating unknown xanthomonads in the classification described by Vauterin et al. (1995).

Although data from the fatty acid analysis were not in agreement with results from DNA-DNA hybridization and FAFLP, this analysis was useful in showing that most of the BBO strains form a tight group. All but two BBO strains formed a cluster with a Euclidian distance of less than $6 \cdot 3$. According to MIDI, strains with a Euclidian distance of approximately less than 6.0 are considered to be the same subspecies or biotype. The two strains originating from Japan (6107 and 6108) were outliers. Strain 6107 has been chosen by Kadota et al. (2000) as the pathotype strain. Based on fatty acid methyl ester analysis, this strain is not typical of the pathovar. Therefore, strain 6369 , which was shown to be typical of the pathovar by all techniques used in this study, was chosen as the probe for DNA-DNA hybridization. It is proposed that strain 6369 should be established as the neopathotype strain for pv. allii.

The present study was also initiated to clarify the host range of BBO strains. All BBO strains were pathogenic to all Allium species assayed. This result is in agreement with those reported by Bowen et al. (1998), but diverged from those described by Kadota et al. (2000). The latter authors determined that $\mathrm{BBO}$ strains were not pathogenic to chive using Allium schoenoprasum L. var. foliosum. In the present work, A. schoenoprasum L. cv. Civette, one of the most common cultivars worldwide, was used. A. schoenoprasum L. grows in a variety of habitats, and many local ecotypes have arisen (Poulsen, 1990). This could explain why $\mathrm{BBO}$ strains are pathogenic to A. schoenoprasum $\mathrm{L}$. but not to the variant foliosum. O'Garro \& Paulraj (1997) listed bean and other plant species of the family Fabaceae as hosts of $\mathrm{BBO}$ strains in Barbados. In the present study, bean leaves inoculated with $\mathrm{BBO}$ strains (including isolates from Barbados) sometimes exhibited small, water-soaked lesions that remained for a few days before turning necrotic, without further expansion of the lesions (data not shown). Our results are consistent with those reported by Alvarez 
et al. (1978). Furthermore, several xanthomonads were reported to induce small, water-soaked lesions when inoculated onto bean (Schnathorst, 1966). Such lesions, which clearly differed from those observed during the compatible interaction between $X$. axonopodis pv. phaseoli and bean, were regarded as non-host interactions. Based on all the above results, the name Xanthomonas axonopodis pv. allii is proposed as the causal agent of BBO.

\section{Description of Xanthomonas axonopodis pv. allii}

Xanthomonas axonopodis pv. allii [al'li.i. N.L. adj. allii from Allium, the genus of onion (Allium cepa L.), Welsh onion (Allium fistulosum L.) and garlic (Allium sativum L.)].

Gram-negative rods, motile with one polar flagellum; obligate aerobes with oxidative metabolism of glucose and catalase-positive. Does not produce cytochrome $c$ oxidase, nitrate reductase, arginine dihydrolase, urease, acetoin or indole. Colonies grown on YPGA after $2-3$ days at $28^{\circ} \mathrm{C}$ are yellow, convex, round and mucoid. Hydrolyses gelatin, casein, aesculin, starch, cellulose and Tween 80 , produces $\mathrm{H}_{2} \mathrm{~S}$ from cysteine and shows pectinolytic activity at $\mathrm{pH} 5 \cdot 0$, $7 \cdot 0$ and $8 \cdot 5$. Cells tolerate up to $3 \% \mathrm{NaCl}$ and grow on YPGA at $35^{\circ} \mathrm{C}$ but not at $40^{\circ} \mathrm{C}$. Fluorescent pigments are not observed. Produces acid from xylose and ribose, but not from melezitose on ARJ medium. Metabolic activity (as assessed by Biolog GN microplates) is shown on the following carbon substrates: dextrin, glycogen, Tween 40, $\mathrm{N}$-acetyl-D-glucosamine, cellobiose, D-fructose, D-galactose, gentiobiose, $\alpha$-D-glucose, lactulose, maltose, D-mannose, D-psicose, sucrose, D-trehalose, methyl pyruvate, monomethyl succinate, cis-aconitic acid, $\alpha$-ketobutyric acid, $\alpha$-ketoglutaric acid, malonic acid, succinic acid, bromosuccinic acid, alaninamide, D-alanine, L-alanine, L-alanyl glycine, L-glutamic acid, glycyl L-glutamic acid, L-proline, $\mathrm{L}$-serine and L-threonine. The following carbon substrates are not utilized: $\alpha$-cyclodextrin, $N$-acetyl-D-galactosamine, adonitol, L-arabinose, D-arabitol, i-erythritol, m-inositol, $\alpha$ D-lactose, D-mannitol, methyl $\beta$-D-glucoside, L-rhamnose, D-sorbitol, xylitol, formic acid, D-galactonic acid lactone, D-galacturonic acid, D-gluconic acid, D-glucosaminic acid, D-glucuronic acid, $\gamma$-hydroxybutyric acid, $p$-hydroxyphenylacetic acid, itaconic acid, quinic acid, D-saccharic acid, sebacic acid, glucuronamide, L-histidine, L-ornithine, Lphenylalanine, L-pyroglutamic acid, D-serine, DL-carnitine, $\gamma$-aminobutyric acid, urocanic acid, inosine, uridine, thymidine, phenylethylamine, putrescine, 2-aminoethanol, 2,3-butanediol and glucose 6-phosphate.

Induces typical BBO symptoms on leaves of onion (Allium cepa L.), garlic (Allium sativum L.), chive (Allium schoenoprasum L.), leek (Allium porrum L.), shallot (Allium cepa var. ascalonicum Backer) and Welsh onion (Allium fistulosum L.). Characteristic leaf lesions start as lenticular, water-soaked spots, which extend and eventually coalesce. Lesions progress into dry, chlorotic spots with tissue collapse and holes. Severe infections induce leaf dieback, resulting in a reduction in bulb size. Not pathogenic to
Allium schoenoprasum L. var. foliosum Rgl., Chinese chive (Allium tuberosum Rottler), hyacinth (Hyacinthus orientalis L.) or bean (Phaseolus vulgaris L.). The DNA G $+\mathrm{C}$ content is $62 \cdot 3-62 \cdot 7 \mathrm{~mol} \%$. The proposed neopathotype strain is CFBP $6369=$ LMG 21894 .

\section{ACKNOWLEDGEMENTS}

We wish to express our appreciation to D. Stead, S. Benimahdu, S. Saumtally, Z. Amat-Novo, A. Alvarez, A. Schwartz, L. Mabena, G. Trujillo, J. R. Rodrigues Neto and MAFF Genebank Administration Division for providing bacterial cultures and A. Couteau, S. Belouin, C. Brin, S. Bonneau and A. Huard for technical assistance. This work was funded by CIRAD, ODEADOM, Conseil Général de la Réunion and Union Européenne (DOCUP Réunion 2000-2006 objectif 1).

\section{REFERENCES}

Alvarez, A. M., Buddenhagen, I. W., Buddenhagen, E. S. \& Domen, H. Y. (1978). Bacterial blight of onion, a new disease caused by Xanthomonas sp. Phytopathology 68, 1132-1136.

Ausubel, F. M., Brent, R., Kingston, R. E., Moore, D. D., Seidman, J. G., Smith, J. A. \& Struhl, K. (1995). Current Protocols in Molecular Biology. New York: Wiley.

Bowen, P., Gibbs, H. A. A. \& O'Garro, L. W. (1998). Garlic, chives, shallot and leek are alternative hosts to Xanthomonas campestris, the pathogen of leaf blight of onion Allium cepa L. Seventh International Congress of Plant Pathology, pp. 6-96. Edinburgh, UK: ISPP.

Brenner, D. J., McWhorter, A. C., Knutson, J. K. \& Steigerwalt, A. G. (1982). Escherichia vulneris: a new species of Enterobacteriaceae associated with human wounds. J Clin Microbiol 15, 1133-1140.

Crosa, J. H., Brenner, D. J. \& Falkow, S. (1973). Use of a singlestrand specific nuclease for analysis of bacterial and plasmid deoxyribonucleic acid homo- and heteroduplexes. J Bacteriol 115, 904-911.

Dye, D. W., Bradbury, J. F., Goto, M., Hayward, A. C., Lelliott, R. A. \& Schroth, M. N. (1980). International standards for naming pathovars of phytopathogenic bacteria and a list of pathovar names and pathotype strains. Rev Plant Pathol 59, 153-168.

Frey, P., Frey-Klett, P., Garbaye, J., Berge, O. \& Heulin, T. (1997). Metabolic and genotypic fingerprinting of fluorescent pseudomonads associated with the Douglas fir Laccaria bicolor mycorrhizosphere. Appl Environ Microbiol 63, 1852-1860.

Garland, J. L. (1996). Analytical approaches to the characterization of samples of microbial communities using patterns of potential C source utilization. Soil Biol Biochem 28, 213-221.

Gascuel, O. (1997). Concerning the NJ algorithm and its unweighted version UNJ. In Mathematical Hierarchies and Biology, vol. 37, pp. 149-171. Edited by B. Mirkin, F. R. McMorris, F. Roberts \& A. Rzhetsky. Providence, RI: American Mathematical Society.

Grimont, P. A. D. (1988). Use of DNA reassociation in bacterial classification. Can J Microbiol 34, 541-546.

Grimont, P. A. D., Popoff, M. Y., Grimont, F., Coynault, C. \& Lemelin, M. (1980). Reproducibility and correlation study of three deoxyribonucleic acid hybridization procedures. Curr Microbiol 4, 325-330.

Hauben, L., Vauterin, L., Swings, J. \& Moore, E. R. B. (1997). Comparison of $16 \mathrm{~S}$ ribosomal DNA sequences of all Xanthomonas species. Int J Syst Bacteriol 47, 328-335. 
Hildebrand, D. C. (1971). Pectate and pectin gels for differentiation of Pseudomonas sp. and other bacterial plant pathogens. Phytopathology 61, 1430-1436.

Isakeit, T., Miller, M. E., Barnes, L. W., Dickstein, E. R. \& Jones, J. B. (2000). First report of leaf blight of onion caused by Xanthomonas campestris in the continental United States. Plant Dis 84, 201.

Janssen, P., Coopman, R., Huys, G., Swings, J., Bleeker, M., Vos, P., Zabeau, M. \& Kersters, K. (1996). Evaluation of the DNA fingerprinting method AFLP as a new tool in bacterial taxonomy. Microbiology 142, 1881-1893.

Jones, J. B., Bouzar, H., Stall, R. E., Almira, E. C., Roberts, P. D., Bowen, B. W., Sudberry, J., Strickler, P. M. \& Chun, J. (2000). Systematic analysis of xanthomonads (Xanthomonas spp.) associated with pepper and tomato lesions. Int J Syst Evol Microbiol 50, 1211-1219. Kadota, I., Uehara, K., Shinohara, H. \& Nishiyama, K. (2000). Bacterial blight of Welsh onion: a new disease caused by Xanthomonas campestris pv. allii pv. nov. J Gen Plant Pathol 66, 310-315. Lelliott, R. A., Billing, E. \& Hayward, A. C. (1966). A determinative scheme for the fluorescent plant pathogenic pseudomonads. J Appl Bacteriol 29, 470-489.

Marmur, J. \& Doty, P. (1962). Determination of the base composition of deoxyribonucleic acid from its thermal denaturation temperature. J Mol Biol 4, 109-118.

Moore, E. R. B., Kruger, A. S., Hauben, L., Seal, S. E., De Baere, R., De Wachter, R., Timmis, K. N. \& Swings, J. (1997). 16S rRNA gene sequence analyses and inter- and intrageneric relationships of Xanthomonas species and Stenotrophomonas maltophilia. FEMS Microbiol Lett 151, 145-153.

Mougel, C., Thioulouse, J., Perrière, G. \& Nesme, X. (2002). A mathematical method for determining genome divergence and species delineation using AFLP. Int J Syst Evol Microbiol 52, 573-586.

Nesme, X., Vaneechoutte, M., Orso, S., Hoste, B. \& Swings, J. (1995). Diversity and genetic relatedness within genera Xanthomonas and Stenotrophomonas using restriction endonuclease site differences of PCR-amplified 16S rRNA gene. Syst Appl Microbiol 18, 127-135.

Neto, J. R., Malavolta, V. A., Jr, Cardelli, M. A. \& Sinigaglia, C. (1987). Ocorrencia de uma nova doença bacteriana em cebola, no estado de Sao Paulo. Summa Phytopathol 13, 10 (in Portuguese).

Norman, D. J., Chase, A. R., Hodge, N. C. \& Stall, R. E. (1997). Differentiation of three species of Xanthomonas and Stenotrophomonas maltophilia using cellular fatty acid analyses. Eur J Plant Pathol 103, 687-693.

Nunez, J. J., Gilbertson, R. L., Meng, X. \& Davis, R. M. (2002). First report of Xanthomonas leaf blight of onion in California. Plant Dis 86, 330 .

O’Garro, L. W. \& Paulraj, L. P. (1997). Onion leaf blight caused by Xanthomonas campestris: alternative hosts and resistant onion genotypes. Plant Dis 81, 978-982.

Owen, R. J. \& Lapage, S. P. (1976). The thermal denaturation of partly purified bacterial deoxyribonucleic acid and its taxonomic applications. J Appl Bacteriol 41, 335-340.

Paulraj, L. \& O'Garro, L. W. (1993). Leaf blight of onions in Barbados caused by Xanthomonas campestris. Plant Dis 77, 198-201.

Poulsen, L. (1990). Chives Allium schoenoprasum L. In Onion and Allied Crops, vol. III, pp. 231-250. Edited by J. L. Brewster \& H. D. Rabinowitch. Boca Raton, FL: CRC Press.

Rademaker, J. L. W. (2000). Computer-assisted pattern analysis of rep-PCR genomic fingerprints in the molecular systematics of Xanthomonas. PhD thesis, Gent University, Belgium.

Rademaker, J. L. W., Hoste, B., Louws, F. J., Kersters, K., Swings, J., Vauterin, L., Vauterin, P. \& de Bruijn, F. J. (2000). Comparison of AFLP and rep-PCR genomic fingerprinting with DNA-DNA homology studies: Xanthomonas as a model system. Int J Syst Evol Microbiol 50, 665-677.

Riley, M. S., Cooper, V. S., Lenski, R. E., Forney, L. J. \& Marsh, T. L. (2001). Rapid phenotypic change and diversification of a soil bacterium during 1000 generations of experimental evolution. Microbiology 147, 995-1006.

Roumagnac, P., Jeuffrault, E., Pruvost, O., Chéron, J. J. \& Girard, J. C. (1997). Identification d'une bactérie du genre Xanthomonas pathogène de l'oignon à l'île de la Réunion. Cinquième Conférence Internationale sur les Maladies des Plantes, pp. 673-680. Tours, France: ANPP (in French).

Roumagnac, P., Gagnevin, L. \& Pruvost, O. (2000). Detection of Xanthomonas sp., the causal agent of onion bacterial blight, in onion seeds using a newly developed semi-selective isolation medium. Eur J Plant Pathol 106, 867-877.

Sanders, F. H., Langston, D. B., Jr, Brock, J. H., Gitaitis, R. D., Curry, D. E. \& Torrance, R. L. (2003). First report of a leaf blight of onion caused by Xanthomonas spp. in Georgia. Plant Dis 87, 749.

Schnathorst, W. C. (1966). Unaltered specificity in several xanthomonads after repeated passage through Phaseolus vulgaris. Phytopathology 56, 58-60.

Schwartz, H. F. \& Otto, K. (2000). First report of a leaf blight of onion caused by Xanthomonas campestris in Colorado. Plant Dis 84, 922. Scortichini, M. \& Rossi, M. P. (1995). Influence of subculturing some phytopathogenic bacteria on their carbohydrate utilizing profile. Lett Appl Microbiol 21, 237-241.

Serfontein, J. J. (2001). Xanthomonas blight of onion in South Africa. Plant Dis 85, 442.

Stackebrandt, E., Frederiksen, W., Garrity, G. M. \& 10 other authors (2002). Report of the ad hoc committee for the re-evaluation of the species definition in bacteriology. Int J Syst Evol Microbiol 52, 1043-1047.

Swings, J., Vauterin, L. \& Kersters, K. (1993). The bacterium Xanthomonas. In Xanthomonas, pp. 121-156. Edited by J. G. Swings \& E. L. Civerolo. London: Chapman \& Hall.

Thioulouse, J., Chessel, D., Doledec, S. \& Olivier, J. M. (1997). ADE4: a multivariate analysis and graphical display software. Stat Comput 7, 75-83.

Thomas, W. D. J. \& Weinhold, A. R. (1953). Xanthomonas striaformans, a new bacterial pathogen of onion. Colorado Wyoming Acad Sci J 4, 23.

Trébaol, G., Gardan, L., Manceau, C., Tanguy, J.-L., Tirilly, Y. \& Boury, S. (2000). Genomic and phenotypic characterization of Xanthomonas cynarae: a new species that causes bacterial bract spot of artichoke (Cynara scolymus L.). Int J Syst Evol Microbiol 50, 1471-1478.

Trujillo, G. \& Hernandez, Y. (1999). Identificacion de bacterias fitopatogenas en semillas de plantas cultivadas. XVI Congreso Venezolano de Fitopatologia. Barquisimeto, Venezuela: Sociedad Venezolano de Fitopatologia (in Spanish).

Vauterin, L., Hoste, B., Kersters, K. \& Swings, J. (1995). Reclassification of Xanthomonas. Int J Syst Bacteriol 45, 472-489.

Vernière, C., Devaux, M., Pruvost, O., Couteau, A. \& Luisetti, J. (1991). Studies on the biochemical and physiological variations among strains of Xanthomonas campestris pv. citri, the causal agent of citrus bacterial canker disease. Fruits 46, 162-170.

Ward, J. H. J. (1963). Hierarchical grouping to optimize an objective function. Am Stat Assoc J 58, 236-244.

Wayne, L. G., Brenner, D. J., Colwell, R. R. \& 9 other authors (1987). International Committee on Systematic Bacteriology. Report of the ad hoc committee on reconciliation of approaches to bacterial systematics. Int J Syst Bacteriol 37, 463-464. 